\title{
The Study on Spatial Structure Distribution Characters of Coastal Tourism Resources in Hebei Province
}

\author{
Jinguo Zhao, a, Yujuan $\mathrm{Chu}^{2, \mathrm{~b}}$ and Xiaoqing $\mathrm{Han}^{3, \mathrm{c}, *}$ \\ ${ }^{1}$ Gansu Normal University for Nationalities, Hezuo, 747000, China \\ ${ }^{2}$ No.2 Experimental Middle School of Shijiazhuang, Shijiazhuang 051130, China \\ ${ }^{3}$ Hebei Utilization and Planning Institute of Land Resources, Shijiazhuang 050051, China \\ a76419774@qq.com, bchu_yujuan@126.com, cxqhan312@126.com
}

\begin{abstract}
In order to study the spatial structure and research the distribution characters of coastal tourism resources in Hebei Province, the paper took 151 units as study subjects to comprehensive analysis the space structure conditions of coastal tourism resources by the method of summarize. The results were shown that, except 9 units in every coastal cities, there were 151 units of coastal tourism resources in Hebei Province, and the other 142 units were in different area. 3 kind coastal physiognomies, rock coast and sand coast plain and plain muddy coast, were matched with the spatial distribution conditions of tourism resources. Meanwhile, they were matched with each other between economic development level and the spatial distribution conditions of tourism resources. The best matched-degree was Qinhuangdao City, and the second one was Tangshan City, and the last one was Cangzhou City because it was developed later than the other 2 cities.
\end{abstract}

Keywords: tourism resources; spatial structure; distribution characteristic; study.

\section{Introduction}

There are 151 units of coastal tourism resources in Hebei Province, of which 9 are in every coastal cities, Qinhuangdao City and Tangshan City and Cangzhou City, and the others are in different coastal cities except climate and custom (table 1). There are 142, about 80\%, units of coastal tourism resources in Qinhuangdao City. The most one is 42, which is about 30\%, units of coastal tourism resources in Beidaihe District. The second is 31, about 22\%, in Shanhaiguan District. The third is 16, about $11 \%$, in Changli County. The nest one is 15, about $10 \%$, in Haigang District. The lease one is only 9, about 6\%, in Funing County. There are19 units of coastal tourism resources in Tangshan City, and only one is in Tanghai County, and the others are in Laoting County. There are 11, about 8\%, in Cangzhou City, which is the lease one in coastal cities of Hebei Province [1].

Table 1 The table of spatial distribution condition of coastal tourism resources in Hebei Province

\begin{tabular}{cccccccccc}
\hline \multirow{2}{*}{ Subject } & \multirow{2}{*}{ Total } & \multicolumn{9}{c}{ Qinhuangdao City } & Tangshan & Cangzhou \\
\cline { 3 - 8 } & & Subtotal & S. D. & H. D. & B. D. & F. C. & C. C. & City & City \\
\hline Unit & 142 & 113 & 31 & 15 & 42 & 9 & 16 & 18 & 11 \\
Ratio(\%) & 100 & 79 & 22 & 10 & 30 & 6 & 11 & 13 & 8 \\
\hline
\end{tabular}

Remark: S. D. is Shanhaiguan District; H. D. is Haigang District; B. D. is Beidaihe District; F. C. is Funing County; C. C. is Changli County. 9 units, in every coastal cities, are not calculated in this table.

\section{The Match Condition between Coastal Physiognomy Type and Spatial Distribution of Tourism Resources}

Rock Coast and Tourism Resources. The rock coast of Hebei Province is lie from Zhangzhuang to Beidaihe River, where are some estuarine coastal landscapes, such as the Dashihe River, Xinkaihe River, Tanghe River, Chituhe River, Daihe River and so on. The rock coast is made up metamorphic granodiorite and quartz reef. There are some geomorphologic landscapes of $20.5 \mathrm{KM}$ length coastline with Reefs, sea cliff, sea cave, sea cave, Marine arch bridge and so on. Therefore, it is a good strategic position of watching the sea, in the meantime, it is the perfect position to building the port. There are 
the tower of Great Wall of natural landscapes and the humanities landscapes architecture, as the Eight-Power Allied Forces military camp in the nearby and the Tanah Lot temple. In addition, there are the ocean hydrological stations and lighthouse, which develop to the Qinhuangdao Port. Meanwhile, it is the asking immortal position of the first emperor of Qin, and it is said that the first emperor of Qin dispatched feet to seek the medicine of living forever. As the result it is the sea port since ancient times.

There is a fine bay bathing beach in the front of the beach and a Lianfengshan Mountain, $153 \mathrm{~m}$ height, with east to west trend nearby the sea. Between the mountain and sea there are gullies with luxuriant foliage and tranquil environment and pleasant weather, predominant conditions for summer resort of coast, because of which it had been the seaside resorts since Qing Dynastic.

Plain Sandy Coast and Tourism Resources. It is the plain sandy coast from Daihe River to Daqinghe River, and there are many tourism resources, which refer to 4 different types, such as International Entertainment Center, Changli Golden Coast, Laoting Blue Sea Bathing Beach and Tangshan Port.

The river type coast from Daihe River to Dapuhe River. It is the plain longshore bar sandy coast, mainly silver sand, with the $40-60$ meters width and $4-8$ degrees slope. There are the longshore bar of 1.5 - 2 meters height and 2 -3 meters width behind of which are the coast protection forest. Due to the sandy coast and clean sea water, they are the good natural bathing beaches, too, such as the Tianma bathing beach of Nandaihe River, International Entertainment Center and so on. And there are some area suitable to bathing beaches which are still not developed.

The dune type coast in Golden Beach. There are several $40 \mathrm{~km}$ seashore longitudinal dune ranges from Dapuhe River to the north of modern Luanhe River delta. They are made by the sediment of the Luanhe River which are moved and deposited by sea, wind and so on. The Dayuding Dune, the largest dune, is about $44 \mathrm{~m}$ height. With the beautiful landscape, made by sand, clean sea, blue sky and green forest, it is famous both at home and abroad. And now it is part of the Changli Golden Beach National Ocean Natural Preserve. Due to the loose sand, clean sea and wide view, the Golden coast, $40-100 \mathrm{~m}$ width, is a better bathing beach with great potentiality to be developed.

The delta type coast in the Luanhe River. The Luanhe River Delta is a typical plain big river delta. There are some underwater barriers, especially in outside of estuary areas, due to the low topography and messy rivers, which are formed the typical barrier-lagoon estuary landscapes.

The low plain sandy coast. The coastline from Luanhe River to Daqinghe River is made of the low plain sandy coast and sand islands which are made of sediment discharge into the sea moved and deposited from Luanhe River and Daqinghe River in Laoting County. The Treasure Bathing Beach has been degraded because of smoke pollution from Jingtang Port and a few muddy coastline which lead to the muddy sea water and low quality of bathing beach. Outside the Daqinghe River estuary there are a few sand islands such as Shijiutuo Island, Dawanggang Island, Yuetuo Island, Xituo Island, Caofeidian Island and so on. Except the Shijiutuo Island is the erosion island, the others are deposition offshore sand island with the NNE to SSW direction. Some of them are almost inundated in high tide, some are not inundated in high tide, where are sandy vegetation, can be the good bathing beaches due to clean sea and they are lagoon inside developed into the scallop farms.

Plain Muddy Coast and Tourism Resources. There are two parts of muddy plain coastline, one part is from Daqinghe River in Tangshan City to Jianhekou River in Tianjin City, another is in Cangzhou City. The coastline of Tangshan City, the plain of the ancient Luanhe River, including the west of Laoting County, Tangshan County, Luannan County and Fengnan County, is the downstream river of Dazhuanghe River, Xihe River, Qinglonghe River and Jianhe River with more paddy lands, aquafarms and salt pans due to the low terrain.

It is the marine plain coast with a shell ridge, 4-5 $\mathrm{m}$ height and about $6 \mathrm{~m}$ width, which has been almost destroyed and has been built seawall. There are some geomorphic types like the low saline land, ancient lagoon and so on. The near shore tidal beaches have been developed to the aquaculture farms, and the saline lands have been developed into salt pans. Meanwhile the ancient lagoons, like Nandagang Port, have been transformed the reservoir wetlands [2]. These plain muddy coasts have been valued of tourism to develop with the beautiful landscape. 


\section{The Match Condition between Economic Development Level and Spatial Distribution of Tourism Resources}

The spatial distribution of coastal tourist resources has been affected not only by natural factors as coastal physiognomy and climate but also by human factors as developing history and economic development level in Hebei Province. The same as humanistic tourism resources.

The Tourism Resources of Scenic Spots and Historic Sites in Shanhaiguan Taking the Great Wall as Subject. The Shanhaiguan, lies in between the Jiaoshan Mountain and the Bohai Sea, has been a very important military base since antiquity. The Yuguan, had been built before Ming Dynasty, has been changed the name as Shanhaiguan since the Shanhaiguan fortress and the Great Wall here had been built in 1381 of Ming Dynasty. In the meantime, the Ninghai fortress, named Laolongtou, was built in the mouse into the sea of the Great Wall with 600 years history [3]. There are too many places of interest about the Great Wall and fortress such as the first pass under heaven, Shanhaiguan fortress, Laolongtou, Chenghai floor, Haishen temple, Mengjiangnv temple, new build museum of the Great Wall and so on. There are about 31 tourism resources in Shanhaiguan which is the second County administrative unit of tourism resources. Except that there are the garrison of eight camp and the martyr field to commemorate martyrs sacrificed in Shanhuaiguan Battle during the liberation war.

The Port Tourism Resources Taking the Port and City as Subject. It has been built as the port city since Qing Dynasty in Haigang District of Qinhuangdao City. And it is a fine natural harbor with the lesser waves and non-icing in winter and dominant position. After more than 100 years development it is the second largest port in domestic. Due to the port development there are not only developing other industries and public areas as bathing beach and park but also new building the other famous tourism resources like sports facilities and Xinao Underwater world.

The Coastal Tourism Resources with Long History in Beidaihe Taking Summer Resort and Taking the Holiday as Subject. It has been about 2200 years history since First Emperor of Qin built temporary imperial palace in Beidaihe coast. It could be further proved to develop for a long time by building Jinshanwei Fortress in Ming Dynasty. All in one word, there are the fine natural conditions and landscapes to be the summer resorts. The English engineers surveyed here and reported the bathing beaches and landscapes in 1893. Soon after, the Qing Government allowed the people at home and abroad to live here together. So it is the pioneer for coast summer resort in our county with more than 100 years history. The characters of tourism resources, taking summer resort and holiday as subject, are not only large densities and quantities and high degree of development but also big value and high popularity [4]. Except many bay type bathing beaches and nearly one thousand villas, there are too many tourist resorts to view sea and see the sunrise in Lianfengshan Mountain and bedrock capes. Meanwhile, there are some human landscapes such as famous buildings, parks, archaic sculptures, steles, palace ruins, new building agro-ecological park of Jifa, zooms and the Biluo Tower and so on. There are about 42 tourism resources, about $30 \%$ of county administrative units in Beidaihe.

The Coastal Tourism Resources of New Building Holiday Resort in Nandaihe Taking Fine Bathing Beaches as Subject. The Naidaihe development zones, fine bathing beaches and great development potentiality, have been developed into a new tourism zones since the $1980 \mathrm{~s}$. The new building International Entertainment Center, take sand skiing and grass skating and water skiing as subject, has been achieved good economic benefits with the situation of coastal and marine tourism development. Meanwhile, the new building artificial island, named Xianluodao Island, and the other nearby artificial landscapes have been developed to be the tourism resources with human characteristics. Because of single type coast and new development there are only 9 tourism resource.

The Tourism Resources in Changli Golden Coast Taking Sand and Sea as Subject. There are some new building resort facilities in Jiaozhuang Village, lies in the north of Changli Golden Coast, less than 20 years history of development since $1980 \mathrm{~s}$. And there are some sand skiing fields and about 3 to 4 bathing beaches in the middle of Changli Golden Coast [5]. Except that there are shooting gallery and flying form field. The same as Haigang District, there are 16 tourism resources, about $11 \%$ of county administrative units in Changli County. 
The Tourism Resources in Laoting County Taking Sand Beach and Island as Subject. The sand beaches, nearby Jingtang Port, have been degraded as the pollution of Jingtang Port which has been built in last 1990 s. There are 3 island, named Shijiutuo Island and Yuetuo Island and Dawanggang Island, lie outside of Daqinghe River estuary. Shijiutuo Island has been now developed into a tourism island since the $1980 \mathrm{~s}$. Except Shijiutuo Island, the other 2 islands are developed in the last few years with different degrees of damage in ecological environment because of privately operated and individual investment. The same as Haigang District and Changli City, there are 19 tourism resources, about $13 \%$ of county administrative units in Laoting County.

The Coast Tourism Resources in Cangzhou City Taking the Building of Huanghua Port as Subject. Because of low topography and desolate salt, it is later than other cities in development history. Though there have been developed coastal economies, such as salt pans and aquaculture ponds, and built the South Port and Bilateral Farm after the founding of the PRC, it is still in the condition of economic backwardness because of development later. But the situation has been changed since the Huanghua Port is built. The new economic structures appear as the Huanghua Port as subject, and because of which some new tourism resources could be de developed such as mud baths in mudflat, eco-tourism of salt industry, eco-tourism of the South Port, spring resort tour, tourism for scientific investigation of volcanic landform and the ancient shell dike. Although there are only 11 tourism resources, it will be developed in height exploring potential.

\section{Summary}

After comprehensive analysis the space structure characters of coastal tourism resources in Hebei Province, the results are as following.

Firstly, there were 151 units of coastal tourism resources in Hebei Province, and the other 142 units were in different area.

Secondly, 3 kind coastal physiognomies, rock coast and sand coast plain and plain muddy coast, were matched with the spatial distribution conditions of tourism resources.

Thirdly, they were matched with each other between economic development level and the spatial distribution conditions of tourism resources. The best matched-degree was Qinhuangdao City, and the second one was Tangshan City, and the last one was Cangzhou City because it was developed later than the other 2 cities.

\section{References}

[1] Fenghua Zhao, Xu Ling. The study of development and utilization of tourism resource in Hebei Province. Enterprise of Hebei. 6 (2014) 49-50.

[2] Jiaqi Cong. On the integration of the tourism resources of Hebei, Journal of Shijiazhuang Vocational Technology Institute. 20 (2008) 17-19.

[3] Zhihua Xie, Bihu Wu. Tourism Spatial structure of resources-based attractions in China. Scientia Geographica Sinica. 28 (2008) 748-753.

[4] Yuanshui Huang, Ganghua Chen. Spatial structure of tourist attractions in Fujian Province statistic analysis based on the national 3A level- above tourist attractions, ECONOMIC GEOGRAPHY. 30 (2010) 1195-1199.

[5] Gang Li, Fang Lv, Ying Lu. A Study on the Evolvement of Resort System Spatial Structure of the Pole-Axis Theory in Liaoning Province, Journal of Liaoning Normal University. 29 (2006) 238-240. 